John Carroll University

Carroll Collected

\title{
The Short and Surprisingly Private Life of King Bolo: Eliot's Bawdy Poems and Their Audiences
}

Jayme Stayer

John Carroll University, jstayer@jcu.edu

Follow this and additional works at: https://collected.jcu.edu/fac_bib_2017

Part of the English Language and Literature Commons, and the Poetry Commons

\section{Recommended Citation}

Stayer, Jayme, "The Short and Surprisingly Private Life of King Bolo: Eliot's Bawdy Poems and Their Audiences" (2017). 2017 Faculty Bibliography. 14.

https://collected.jcu.edu/fac_bib_2017/14 


\title{
The Short and Surprisingly Private Life of King Bolo: Eliot's Bawdy Poems and Their Audiences
}

\author{
Jayme Stayer
}

I

ntimations of Eliot's bawdy verses started to leak out during the author's lifetime. Confidants of the poet teased the public about their existence, and Eliot himself joked with interviewers about a character named King Bolo. In the 1980s, biographies and a volume of letters offered the first idea of the scope of the obscene verse. And then, in 1996, Inventions of the March Hare was published. In an appendix judiciously labeled "Poems excised from the Notebook," the editor reproduced several pages of obscene verse-including the Columbo and Bolo poems-that Eliot had torn out before selling the notebook to John Quinn. Reviewed in the popular press and dissected in scholarly journals, these poems became notorious for their scatological and pornographic content, and more troublingly, for the violence, racism, misogyny, and homophobia of such lines as: "The only doctor in his town / Was a bastard jew named Benny" and "Up from Possum Stew!' / Or 'How I set the nigger free!" and the jolly tinker whose "whanger" "ripped up my belly from my cunt to my navel."1 Commentators have alternately shrugged at these poems, explained them, explained 
them away, or expressed astonishment or outrage at their content. ${ }^{2}$ Most recently, with the 2015 publication of the magisterial Poems of T. S. Eliot, the scattered appearances of the Bolo sequence have been sewn together in a composite to which the editors have given the title "The Columbiad," and where all forty-nine stanzas are finally on view, awaiting the judgment of the future. ${ }^{3}$

By way of entering this debate, I want to consider three questions that scholars have not yet thought to ask about these poems: (1) Did Eliot really try to publish his obscene verses in Wyndham Lewis's Blast? (2) Was the elderly Eliot still composing Bolo verses? (3) And if so, were they written in the same racist and misogynist vein as in his youth? Without sufficient proof, and without looking carefully at the available evidence, scholars have assumed that the answer to these questions is "yes." I would like to offer multiple reasons for responding with a qualified "no" on all three counts. ${ }^{4}$

Though these three questions seem to address narrow issues of historical fact, their answers open onto the contested spaces of what these poems mean and why they have provoked such disapproval. The first question, whether Eliot really intended to place bawdy lyrics in Blast, is not only one of historical accuracy; it is also one of audience, and thus of understanding the poems' rhetoric. For whom did Eliot write these poems, where did he imagine they would appear as he was composing them, and what public and private venues did he, in point of fact, seek for their readership? The belief that Eliot tried to publish obscene poems in Blast has led some to think, erroneously, that Eliot took these verses more seriously than he actually did, that he had the poor taste to believe that their circulation outside his immediate circle of friends was appropriate, and that he was foolish enough not to realize that they would damage his reputation. Correcting the historical record on this matter, while a salutary task in its own right, has another consequence: it restores to Eliot his consciousness that these verses were extremely transgressive.

The second and third questions-how late was Eliot writing Bolo poems, and what is their content?-are likewise not just concerns 
about chronology or accurate paraphrase. Both questions touch on Eliot's bigotry in light of his later conversion: what are we to think of an elder statesman and Christian convert who wrote poems of spiritual humility for public consumption while supposedly scribbling away at racist and misogynist poems in private? The belief that Eliot continued to compose these obscene poems throughout his life has led some to claim, erroneously, that these verses should not be viewed as juvenilia, but as an abiding interest of his middle and late periods. ${ }^{5}$ As a result, they see the poems as reflecting an ongoing sexual dysfunction, a lifelong immaturity, and a committed misogyny, whereas the poems are more understandable, and less scandalous, as expressions of youthful sexual frustration and facilitators of juvenile masculine bonding.

\section{Eliot's Alleged Intention to Publish His Blue Verse}

That Eliot seriously intended to publish "The Triumph of Bullshit" and "Ballade pour la grosse Lulu" in Blast is a commonplace that no one has yet questioned. ${ }^{6}$ Although this interpretation precedes Christopher Ricks's edition of Inventions of the March Hare (1996), critical agreement regarding Eliot's intentions seemed to be cemented by a skewed reading of two quotations that appear in that volume. On the title page of the appendix, Ricks offers, without commentary, the following excerpts, passages that have been repeated in nearly every critical discussion of these verses:

[Eliot] to Pound, 2 Feb. 1915:

I have corresponded with Lewis, but his puritanical principles seem to bar my way to Publicity. I fear that King Bolo and his Big Black Kween will never burst into print. I understand that Priapism, Narcissism etc. are not approved of, and even so innocent a rhyme as

... pulled her stockings off

With a frightful cry of "Hauptbahnhof!!" is considered decadent. 
Wyndham Lewis to Pound, before July 1915:

Eliot has sent me Bullshit \& the Ballad for Big Louise. They are excellent bits of scholarly ribaldry. I am longing to print them in Blast; but stick to my naif determination to have no "Words Ending in -Uck, -Unt and -Ugger."

The reigning interpretation of this episode is that sometime in early 1915, Eliot sent "The Triumph of Bullshit" and "Ballade pour la grosse Lulu" to Lewis, hoping that he would publish them in Blast. Lewis considered the possibility (so the story goes) but ultimately demurred, explaining his decision both to Pound and to Eliot, with the latter humorously complaining about the rejection. In spite of the unanimity of this interpretation, however, this narrative seems hard to credit. I would like to construct a more probable scenario for the correspondence among Eliot, Pound, and Lewis-one that attends carefully to what these letters are saying and not saying, and one that takes into account a number of important contexts that have so far been ignored.

To understand one of these contexts, it will be helpful to look back five months to September 30, 1914. The war only a few weeks old, Eliot wrote to Conrad Aiken, offering a Bolo verse turned in the service of a patriotic war poem: British heroes sink a German warship, and all are drowned except for the German cabin boy, who "was sav'd alive / And bugger'd, in the sphincter." Ironically commenting on the prospects for the poem's publication, Eliot continues:

The poem was declined by several musical publishers on the ground that it paid too great a tribute to the charms of German youth to be acceptable to the English public. I acknowledg'd the force of the objection, but replied that it was only to be regarded as a punitive measure, and to show the readiness and devotion to duty of the British seaman. ${ }^{8}$ 
This letter to Aiken shows that Eliot was, without question, joking about publishing these Bolo verses. Five months later, writing to Pound, Eliot would adopt this same pose of an unfairly rejected author. The repartee among Eliot, Lewis, and Pound was only the continuation of a motif that Eliot had sounded previously and would extend for some time: namely, pretending to lament that his Bolo sequence would never "burst into print."

To return to the February 1915 exchange, why Pound was involved at all seems to be that Eliot and Lewis had not yet met one another. Pound had probably encouraged Eliot to send some poems to Lewis for editorial consideration; Eliot's introductory gesture- "I have corresponded with Lewis"-elides but implies "as you told me to." Subsequently, "Rhapsody on a Windy Night" and "Preludes" were published by Lewis in Blast in July 1915. Whether Eliot sent obscene verses to Lewis in the same letter as "Rhapsody" and "Preludes" is of less consequence than why Eliot sent him such verses. Eliot often sent blue verse, such as installments of the Bolo sequence, to literary friends and editors with no intention of their being broadcast further. That Eliot sent such poems to Lewis is, in itself, no proof that he wanted them published.

If we look closely at what the letters actually say, Lewis nowhere attributes the idea of printing the poems to Eliot. Lewis writes: "Eliot has sent me Bullshit \& the Ballad for Big Louise," which indicates Eliot's action, but not its intention. Further, Lewis writes: "I am longing to print them," which, read as ironic or not, ascribes the intention to publish to himself rather than to Eliot. Another often missed cue in this correspondence is that Eliot does not bemoan Lewis's rejection of "Bullshit" or "Ballade," the only poems of which Lewis acknowledges receipt. Eliot instead refers to the wider corpus of obscene verse: "I fear that King Bolo and his Big Black Kween will never burst into print." While it strains credulity to imagine Eliot seeking publication for "Bullshit" or "Ballade," vulgar as they are, it is frankly impossible to imagine Bolo's pornography getting into print with Eliot's imprimatur: "a pair of great big hairy balls / And a big black knotty penis." The clues to the tongue-in-cheek tone are unmistakable: Eliot accuses 
Lewis of holding "puritanical principles" (an absurd claim), he sulks histrionically over the imagined rejection, and "decadent" rhyming is given as a primary reason for the refusal. Likewise, when Lewis pretends to be torn between his ban on vulgarity and his "longing" to print the poems, he is not reporting an editorial dilemma but working up a comedic bit for Pound's amusement.

Whether or not Pound was joking is a different matter. In response to Lewis's feigned reluctance, Pound suggests: "I dare say Eliot will consent to leaving blanks for the offending words." ${ }^{10}$ If Pound is in on the joke, then this riposte simply belabors it. But it is possible that Pound was not quite attuned to the prank; his irony was more heavyhanded than his correspondents. ${ }^{11}$ In any event, Eliot has nothing to do with the intention to publish: that Pound would "dare say" what Eliot would agree to demonstrates that Eliot was not included in this side conversation about making the offensive poems more palatable.

At the same time that Eliot and Lewis were joking for Pound's amusement, Pound himself was engaged in the serious business of getting as many of Eliot's poems into print as he could. Indefatigable and generous, Pound was in the midst of a long battle with Harriet Monroe to speed up her publication of "Prufrock" in Poetry. After trying unsuccessfully at The Smart Set, Pound was able to place "Portrait of a Lady" in Alfred Kreymborg's Others, and he directed Eliot to Lewis's Blast, where two poems were placed. Pound himself republished several of Eliot's poems in Catholic Anthology, later claiming that the whole purpose of publishing the volume in London was "in order to get 16 pages of Eliot printed in that damned city." ${ }^{12}$ In the four years preceding his arrival in London, Eliot had published nothing. In 1915, by contrast, Eliot scored twelve publications or reprints, and Pound's intervention was directly responsible for all of them. And so, when Lewis and Eliot kidded to him about publishing "Bullshit," Pound smelled blood in the water.

What happened next in the correspondence between Pound and Lewis is telling. ${ }^{13}$ Pound sent Eliot's "Portrait of a Lady" to Lewis for Blast, ending with the warning: "if you want to use this Portrait you'll 
have to get his permission. =or I will have to."14 In the midst of his tireless crusade to get Eliot published, why does Pound suddenly recall the niceties of permission? Did Eliot, appalled, get wind of Pound's suggestion that "Bullshit" be published with blanks? In response, perhaps Eliot made it clear to Pound that nothing was to be published without his permission. I am conjecturing about such a rebuke, of course, but it would explain Pound's uncharacteristic submissiveness.

The explanation that Eliot might have offered the poems as potentially anonymous contributions falters on the hazards of British obscenity laws. As brash as Pound was, he knew that something like blanks would be needed, and not even a newly arrived foreigner such as Eliot could have believed that the censors, especially vigilant during wartime, would overlook such obscenity. Government censors were on the lookout, and a variety of social purity organizations pressured government agencies to act. As Celia Marshik has explained, the consequences for writers included "visits and surveillance, public proclamations and warnings, and threatening letters as well as trials for obscene libel." ${ }^{15}$

As an editor, Lewis was keenly aware of the pressures of censorship. In June 1914, in a dust-up regarding the first edition of Blast, Lewis's publisher, John Lane, had required that three lines from Pound's poem "Fratres Minores" be blacked out. Chastising Lewis for letting the poem make it so far into press, Lane recalled their earlier agreement "that there would be no sexual disagreeableness or anything which could possibly be construed into libel in it." ${ }^{16}$ The release of Blast, dated June 20,1914, was delayed until July while two women at the Rebel Art Centre crossed out the lines by hand. For Pound as author and Lewis as editor, it was an irritating, humiliating episode. The offending poem by Pound-with its use of the word "testicles" and an oblique description of orgasm-had markedly less "sexual disagreeableness" in it than Eliot's obscene verse. Several months later, the second edition of Blast was due to be published, again by Lane. With the memory of their mutual tussle with Lane fresh in his mind, Lewis expresses to Pound his "naif determination 
to have no 'Words Ending in -Uck, -Unt and -Ugger." With this context restored, it is not only obvious that Lewis is joking about Eliot's verse presenting him with an editorial dilemma, it seems that he is still licking his wounds.

A number of factors have contributed to our misunderstanding of the correspondence among Eliot, Lewis, and Pound. The misreadings of the letters themselves are part of the problem, and these forgotten contexts are another part: (1) Eliot's unmistakable joking about publishing Bolo, joking that both precedes and follows the 1915 episode; (2) the atmosphere of blustery friendship and literary ambition among the three men; and (3) the widely known realities of British censorship, and Lewis's particular history with Lane. In the scenario I am sketching, it was Pound's ambition for Eliot and his bullying manner that came up against an in-joke between two men who were playing to Pound's audience and who were modeling the kind of virile one-upmanship that Pound encouraged. In the static that ensued, Pound missed the tone of the joke and barged ahead with his own plans for Eliot's future.

So far as we know, at no other time in his life did Eliot attempt to publish his obscene verse. ${ }^{17}$ A scenario in which all three men were kidding (or at least Eliot and Lewis were) seems more likely than one in which Eliot momentarily took leave of his senses.

\section{Eliot's Alleged Composition of Bolo Verses Late in Life}

Only one critic has contested the scholarly consensus regarding how late Eliot was writing Bolo verses. Valerie Eliot was in a position to know the most about the composition history of the Bolo poems, but she wrote only two sentences about the matter, and her terse claim has been ignored by critics. Responding to a discussion in the Times Literary Supplement, the poet's widow contested the idea of Bolo's late composition: "It is not true, as William Baker asserts ..., that T. S. Eliot was still writing his 'King Bolo' limericks 'in the late 1950s.' Almost all were written during his Harvard days and none later than 1916."18 
That Eliot kept composing such racist and misogynist poems up to the day he died is another canard abetted partly by misreadings of the archival evidence and partly by the tantalizing presence of the letters up to 1922 (published in 1988) combined with the gaping absence of the later letters (those from 1923 to 1933 have been published between 2011 and 2016). Many scholars have described the existence, dating, and content of Eliot's later Bolo stanzas without offering convincing evidence to substantiate their claims. For example, Bryan Cheyette confidently dates the last Bolo poem to 1964 and gives a blanket description to cover the fifty-year span: "These [Bolo verses] are a long cycle of bawdy, racist, and astonishingly vulgar doggerel which Eliot began writing for a few friends while a student at Harvard and was still writing a year before his death in 1965." ${ }^{19}$ Cheyette's claim is influenced by the work of Gabrielle McIntire, and both Cheyette and McIntire have written important, illuminating chapters on Eliot's Bolo poems. However, for this essay, I want to focus on some of the factual claims they make about the poems' dating and content.

McIntire and Cheyette certainly have good reason to suspect that Eliot was composing installments of the Bolo sequence later in life. Eliot himself seemed to confess the deed in a 1959 interview for The Paris Review. Donald Hall asks: "Do you write anything now in the vein of Old Possum's Book of Practical Cats or King Bolo?” Eliot's initial response seems to refer to both types: "Those things do come from time to time!" After mentioning some incomplete cat poems, he concludes the discussion with an arch reversion to "one": "Oh, yes, one wants to keep one's hand in, you know, in every type of poem, serious and frivolous and proper and improper. One doesn't want to lose one's skill." ${ }^{20}$ Note that this admission-if that is what it is-offers no proof of misogyny, racism, or anything offensive. Once we have examined more recent evidence and identified the important shift that Bolo undergoes in the late 1920s, we will be more likely to see this interchange as a complicitous wink to an interviewer looking to debunk Eliot's saintly authority. 
McIntire claims that the Bolo poems "form part of an extensive cycle that Eliot continued to write throughout his life." ${ }^{21}$ She offers as evidence for this claim numerous references to the Bolo sequence in Eliot's letters:

In the John Davy Hayward Bequest at Cambridge University, for instance, Bolo emerges in a letter to Clive Bell in 1941, nearly fifteen years after an intense correspondence on the subject with Bonamy Dobrée reaches its peak in 1927-astonishingly, the year of Eliot's conversion-and roughly thirty years after Bolo's first incarnation. Furthermore, Conrad Aiken indicates in December 1964, less than a month before Eliot died on 4 January 1965, that Bolo was still a topic of interest. Writing to Eliot at the time, Aiken expresses regret that this year they would not have their usual exchange of Columbo and Bolo poems: "But o dear we shall miss our annual meeting in New York and the exchange of Bolos and lime rickeys at the River Club or Vanderbilt." ... What perhaps is most astonishing about this body of work, then, is that Eliot continued to write and circulate the Columbo and Bolo verses through his whole life. ${ }^{22}$

For McIntire, what is presumably "astonishing" about this evidence is not merely that Eliot kept writing poems about Columbo and Bolo "through his whole life." Rather, what is troublesome is left unstated: that any appearance of Columbo or Bolo is necessarily racist, misogynistic, or otherwise offensive. But once this same evidence is probed in more detail, such assumptions begin to fall apart. The 1941 letter to Clive Bell in which, as McIntire indicates, "Bolo emerges," in point of fact contains no Bolo verses whatsoever. Eliot instead is thanking Bell for some bit of praise, then he remarks on his scheme to complete several long poems (Four Quartets), which prompts this single sentence: "I may even take in hand the long neglected task of putting in order the epical ballad on the life of Chris Columbo (the famous Portuguese 
navigator) and his friends King Bolo and his Big Black Queen." ${ }^{23}$ As Eliot ages, the old joke about publishing Bolo becomes a different, if still obvious joke about giving the sequence a scholarly treatment.

That Bolo emerges in this letter to Bell is true enough; however, he does not emerge in his poetic guise-namely, as the hero of a poem trafficking in racist and misogynist tropes-but in his tamer, prosaic guise as the subject of a mock-editor's scholarly project. The crucial error that critics make in discussing Bolo's longevity is failing to distinguish between the Bolo poems and the Bolo prose, the former occasionally alarming, the latter mostly tedious. A typical passage of Bolo prose, describing the "behaviour of the primitive inhabitants of Bolovia," notes that they are "A notoriously lazy race. They had two Gods, named respectively Wux and Wux. They observed that the carving of Idols out of ebony was hard work; therefore they carved only one Idol." ${ }^{24}$ Such jokes about Bolovian theology or mock discussions of a scholarly edition are hardly "astonishing" at all.

In drawing attention to the differences in tone, form, and content between the Bolo poems and the Bolo prose, I intend to offer clarity rather than plead for a full exoneration. For the Bolo prose has its own ethical problems. Even in these seemingly banal passages I have quoted, Eliot reworks an American prejudice about African-Americans as lazy, and he repeats an offensive epithet created years earlier: the "Big Black Queen." Each of these three words creates problems of racial othering and sexual fetishizing. Similarly, even though the Bolo prose is tamer than the poetry, lampooning tribal customs still betrays condescension toward indigenous peoples. In spite of these qualms, I believe I can still press my point: I am not claiming that the Bolo prose is thoroughly innocent, only that the ethnic humor found therein pales in comparison to the starker prejudices of the Bolo poems. In the Bolo prose, the later Eliot has turned from a poetic corpus of colonialist expansion and sexual deviance toward a mock-sociological study of Bolo's tribal customs. It blurs a useful distinction to place the mild Bolo prose, whatever its problems, in the same moral category as the Bolo verses that spew racial slurs and revel in sexual violence. In 
addition to urging historical and factual accuracy in this discussion, and to identifying the generic conventions and rhetorical aims of the Bolo verse and prose, I am also suggesting that we maintain a delicate ethical balance between distancing ourselves from troublesome prejudices and resisting the facile superiority that comes from scolding a dead person. ${ }^{25}$

\section{"Putting in Order the Epical Ballad": A Bolovian Chronology}

At this stage of discovery, what can be safely claimed about the dating and content of the Bolo poems and prose? The first thing to note is that Christopher Columbo-the oversexed hero of an epic sea journey-is not Eliot's invention. Columbo first appears in a bawdy sea song that scholars variously date to 1876 , after 1877 , and $1893 .{ }^{26}$ Eliot's use is therefore part of a long folk tradition of repetition and variation. Some of the Columbo stanzas that have been preserved in Eliot's notebook are nearly word-for-word transcriptions of pre-existing stanzas, some are adaptations, and others are entirely his own inventions. For the purposes of chronology, I do not distinguish below between verses Eliot has transcribed and verses he has composed; both types are attributed to his hand. However, because a point of contention is whether Eliot kept writing new Bolo verses late in life, I note the difference between the first time a Bolo stanza appears and its subsequent repetition in correspondence.

In their richly annotated edition of The Poems of T. S. Eliot (2015), editors Christopher Ricks and Jim McCue are able to date many of the Bolo and Columbo poems. But several Bolos contain no clear evidence for precise dating. Nevertheless, there is sufficient evidence to place all of the Bolo poems into distinct chronological periods. The Bolo poems that were excised from the Inventions notebook can be roughly dated to the late aughts and early teens. The Bolos that appear within the letters are clearly datable, since Eliot almost always dated his correspondence. This leaves roughly twenty Bolos that have no chronological slot yet. 
These remaining Bolo poems, housed at Yale, were not published in Inventions because they were not clearly linked with the notebook. These twenty-some stanzas were from a smaller pocketbook, of which only six pages remain. As I explain below, I date this pocketbook to the late teens.

\section{Act I, Bolo Begun: Poems 1906-1914}

Certainly the vast majority, and probably all, of the Bolo poems were composed at Harvard. Having examined the correspondence of Eliot's Harvard friends, Robert Crawford concludes that the exchange of Bolo verses was part of their fellowship as undergraduates (1906-10). ${ }^{27}$ Conrad Aiken expands this timeframe, claiming that "hilariously naughty parerga" on the subject of King Bolo served as a "sort of cynical counterpoint to the study of Sanskrit and the treatise on epistemology," extending the sharing of Bolo stanzas into Eliot's graduate student days in America (1911-14). ${ }^{28}$ Given the contemporaneity of the Inventions notebook (begun 1909), some of those verses exchanged among Harvard friends most likely include the Bolo stanzas that were written on its leaves. It is also likely that these same Bolo verses are the ones that Pound saw a few years later in London. From the PoundLewis correspondence cited above, we know that "Bullshit," "Ballade," and other obscene poems predate 1915.

This American period (1906-1914) saw the zenith of Eliot's sexually violent and racially offensive Bolo stanzas. Sexual violence and racial slurs are likewise salient themes in other poems from this period such as "Fragments" and "Ballade pour la grosse Lulu." The verses excised from the notebook were probably not penned after 1914, by which time the notebook had lost steam as a place of invention. This arc of Bolo poems, begun at Harvard, ends with his departure from America in 1914.

\section{Act II, Bolo Collected: Poems 1915-1923}

With Eliot's removal to London, a new and different stage in his life began. Almost all of the Bolos that are datable to this second period 
have been collected from his time in America and transcribed into a pocketbook rather than newly composed. As an artifact, the pocketbook probably dates to the late teens, even though its contents date from much earlier. ${ }^{29}$ My guess is that this smaller pocketbook was purchased later than the Inventions notebook as a way of "putting the epical ballad in order," since these pages have generally neater handwriting, and only Bolo poems appear on them, as opposed to the Inventions notebook, where Bolos are interspersed with the other poems.

Only two new Bolos appear during this period: a brief couplet in 1915 and two stanzas in 1923. But even as early as 1915 a shift in attitude is detectable: these Bolos are already starting to sound mockintellectual rather than shockingly ribald: "pulled her stockings off / With a frightful cry of 'Hauptbahnhof!!"'30 Eliot has a new set of friends to entertain, more witty and learned than his drinking companions from Harvard. The shift from Harvard social clubs, with their regular dinners and occasions, to the London avant-garde, with its epistolary culture, is one possible reason Eliot started collecting Bolos more deliberately in this smaller pocketbook. Columbo, Bolo, and his queen make a crashing exit in a letter to Pound (September 3, 1923) and then disappear for a few years.

\section{Act III, Bolo Transformed: The Bolo Poems and Prose, 1927-1932}

The next datable appearance of Bolo is 1927, when a new arc begins. In this arc, Bolo begins his shift from a hero in a poetic sequence to a specimen in a prosaic study. The impetus for the revival is an extensive discussion of Bolovian customs, which Eliot had initiated with Bonamy Dobrée. The first appearance in this vein is May 10, 1927, where, as we have already seen, Eliot introduces Dobrée to "the primitive inhabitants of Bolovia" as a "notoriously lazy race." ${ }^{31}$ In subsequent letters, he continues in this vein, explaining their cultural customs and liturgical rites. Along with the change from poetry to prose, a concomitant shift can be traced from the historical and sexual matters of the Bolo poems to the anthropological and theological matters of the Bolo prose. This shift in 1927-when Bolo becomes mostly an anthropological/ 
theological joke-exactly corresponds with Eliot's conversion to Christianity. What is a sticking point for McIntire and others is an implied, distasteful hypocrisy: that Eliot, in their understanding, seems to be writing ethically suspect verse in the same year that he adopts a pose of spiritual humility. But now we can see that Eliot's conversion carries with it a deepened commitment to theological discourse and a new interest in the sociological organization of Christian society: the two discourses that Eliot then playfully satirizes in his Bolo prose.

The Bolovian banter with Dobrée continues through 1927, with a few more references in 1928 and 1932. This burst of activity coincides with the creation of the "London Bolovian Society," which Eliot proudly announces to his old college friend, Howard Morris. ${ }^{32}$ Nevertheless, within this discussion very little new verse appears-just a pair of stray stanzas to Morris in late 1929 and two others to Theodore Spencer in $1932 .^{33}$

\section{Act IV, Bolo Mourned: 1940-1964}

Aside from one recycled stanza that appears in 1934, Columbo/Bolo, whether dressed in verse or prose, seems to go underground again for a number of years. ${ }^{34}$ Columbo resurfaces in a letter to Hayward on August 29, 1940, but the stanza is recycled, having originally appeared in the Inventions notebook: "One day Columbo and the queen / They fell into a quarrel / Columbo showed his disrespect / By farting in a barrel." ${ }^{35}$ A few months later, also to Hayward, Eliot quotes a Bolovian description he had sent to Dobrée years earlier: "as King Bolo said to the Queen in presenting Columbo, 'he hunts with the Quorn and shoots over his own coverts." 36 Appearing after a long gap, these mere repetitions point to a lethargy surrounding the topic of Bolo. In the midst of this timeframe, a third transformation materializes, legible in a letter to Hayward on November 25, 1940. No longer the sexual adventurer of the poems nor the object of anthropological study in the prose, now Bolo is hailed wistfully as a former way of life, Bolovian custom providing the pseudo-ancient salutation: "Well, as the Bolovians used to say (and often I feel nostalgia for that blessed isle) 
'Wux-ho!'”37 Next year, the nostalgia endures, Eliot again signing off: "So meanwhile, as the Bolovians used to say (for their happy island has now disappeared): 'wux-ho!"'38 Also in 1941, as we have already seen in Eliot's letter to Clive Bell, he jokes about "putting in order the epical ballad" - the imagined scholarly treatment is a sure sign that Bolo is a fixed, dead canon. ${ }^{39}$

From early 1932 until his death-a thirty-three-year droughtEliot seems to have composed no new Bolo stanzas. A previously unrecorded Bolo poem does appear in a 1956 letter, but it is almost certainly recycled. Writing to his Harvard friend Nick Brooks after a bout of illness, Eliot begins, "I've been slow getting round my friends for their letters of condolence on my approaching demise," and he continues:

So you see that I have some of the resilience of our epoch making heroine the Black Queen -

That vast voluptuous vestal

Who, as you may have forgotten -

Was always Bright and Full of Beans

As well (you may also have forgotten this) -

As well as Blandly Bestial. ${ }^{40}$

Even though the first recorded instance of this stanza comes from a 1956 letter, Eliot is writing to a Digamma Club friend with whom he had shared Bolos at Harvard. ${ }^{41}$ In the poem, Eliot twice reminds Brooks of what has been "forgotten." Thus, the internal and external evidence of the poem suggests that this verse is recycled, one with which his correspondent has long been familiar. Note, also, the queen's transformation: reshaped into a "vestal," if ironic, innocent, she no longer indulges in violent sex, but the "Blandly Bestial" pastime of flatulence.

As with this 1956 letter, occasional repetitions of previously composed Bolos appeared in the latter part of Eliot's life. The last appearance of such is from late 1963 or 1964 . We have already heard 
Aiken's lament in 1964 that there would be no "exchange of Bolos" in the coming year because of Eliot's ill health. Like other tantalizing references to Bolo, it seemed to suggest the existence of newly composed stanzas. But the last Bolo that Eliot sent to Aiken is the same one that he had first shared with his friend fifty years earlier, in 1914:

Now while Colombo + his men

Were feasting at the Passover,

King Bolo and his Big Black Queen

Rolled in tea-kettle-arse-over.

They all sat round the festive board

And dined-on fried hyaenas.

And the King said: "mine's a piece of tail

With a juicy bit of penis." ${ }^{2}$

Similar to the variations that occur in oral tradition, the small divergences of this 1964 stanza from its earlier versions are largely inconsequential. To neglect one of these variations, however, would be to miss a significant shift, though to overlook it would be easy, since it is a change of omission. In a 1927 variant of this stanza, Eliot had jokingly insisted to Dobrée that the stanza was corrupt and that it "should read": "Now the Jewboys of Columbo's Fleet / Were feasting at the Passover." 43 By 1964 though, the anti-Semitic sneer has been deleted or forgotten. Previously scornful of "Jewboys," and once maltreated by a "bastard jew" who had scorched his penis, the 1964 Columbo is now "feasting at the Passover" not only with King Bolo and his queen, but with all his men, joining with - and indistinguishable from-their brother Jews. ${ }^{44}$

David Chinitz was the first to discover that the Bolo stanza that has given the most offense-the one about the "bastard jew named Benny" - was not Eliot's invention at all, but a stanza that appears in the Columbo folk ballad of popular tradition. ${ }^{45}$ Chinitz notes that finding a source does not exonerate this ugliness in Eliot, but the earlier reference does allow Chinitz to express some relief "that this instance of vulgar Jew-baiting originated in the imagination of another." 46 
Likewise, by pointing to the disappearance of "Jewboys" in the 1964 stanza, I am not exonerating Eliot, early or late, on the score of antiSemitism. But it is worth noting that this prejudice seemed to become less impulsive as he aged.

\section{General Notes on Dating and Chronology}

It is probable that Valerie Eliot was exactly right: no new Bolos were written after 1916. Only a small handful of newly recorded Bolos date from 1916-32, and it is possible that their originals, predating 1916, have simply been lost. But even if those stanzas were newly composed, we can still trust Valerie Eliot's general sense of where Bolo belongs: Eliot was mostly finished composing Bolo verses by the time he left America. The few stanzas that appear after this time-such as those offered for Dobrée's instruction in the 1920s-are recycled rather than newly composed. ${ }^{47}$ Those rare Bolo poems that are perhaps written later have lost their vicious bite: the earlier sexual violence and racial prejudice having largely given way to puerile jokes about farting, buggery, and genitalia. ${ }^{48}$ The later Bolo prose is mostly a send-up of academic pedantry. Eliot continued with the Bolo prose somewhat beyond the verse, with a strong burst in the late 1920s, but he was mostly finished with that by 1930 as well. As many Eliot scholars have noted, the poet had a roving intelligence; he was always abandoning a style or concern once he had mastered it or used it up. So one reason Bolo resurfaces in the late 1920s is that Eliot can fit Bolo into a new form (prose explanation) and a new set of concerns (anthropology and theology). This production of Bolovian prose involves the repetition of old Bolo stanzas and, perhaps, the composition of a few new verses. In the early 1940s, he twice expressed nostalgia for Bolo as a figure of his youth, which shows where the whole business stood in his own mind.

It is understandable that McIntire and others, coming across Bolo references in the letters, would assume that Eliot was still churning out such verses when he was in his seventies. To be sure, scattered Bolo references, in hard-to-reach archives, held just this intriguing possibility. However, with the bulk of the letters now becoming publicly 
available, a more complete search does not bear out that conclusion. Given the shift in the 1920s when Bolo became a different kind of joke, and given Eliot's valedictory tone regarding Bolo in the 1940s, it is unlikely that a hidden cache of Bolo poems, datable to the 1920s or later, will ever surface. If a few more Bolos pop up in unexpected places, I doubt that they would mar the broad picture I am sketching here: that a middle-aged and then elderly Eliot did not set himself to the task of composing Bolo verses as a way of expanding the already existing sequence. ${ }^{49}$

\section{The Bolo Poems vs. The Columbiad}

The first complete edition of The Poems will no doubt become the standard reference for discussion of the Bolo sequence, as the two volumes finally publish the remaining stanzas from the Yale archive and the other scattered Bolos from as-yet-unpublished correspondence. The newly published Bolos in turn are brought together with the previously published stanzas, fixing some minor errors in the process. The luxurious detail, scholarly apparatus, and new format in which the Bolo poems are presented augur both opportunity and risk for critics.

A potential hazard of the explanatory material is that the carefully dated sources may encourage the reader to mistake an appearance of a Bolo stanza for its date of composition, thus reinscribing the fallacy that Eliot spent his life composing the sequence. Another mild, if understandable problem concerns the textual history: the editors prudently decline to print every variant of the Bolo verses-a practice that would have further consecrated these lightweight poems. ${ }^{50}$ However, the absence of variants and their dates means that the new edition, while exhaustive in many respects, cannot guide a scholar in tracking conceptual and attitudinal shifts, nor can it help sort out when Eliot wrote a new Bolo and when he repeated it.

It is worth recalling that even though Eliot collected a number of the Bolo stanzas in an early pocketbook, he did so for private reasons, not for publication. Eliot himself never collected the nearly fifty poems 
together, either for private or public usage, nor did he direct anyone else to do so. A danger of sprucing up and regularizing the poems is that it confers a seriousness of purpose that the originals did not intend to convey. Likewise, the editors' imposition of a formal title, The Columbiad, and the format and numbering of stanzas confer a tangible literary authority: they are no longer improvised poems but a textually coherent epic, if a mock one. Another problem is that the settings of the poems pinball around the globe, but the editors soft-pedal this chaos, imposing a quasi-narrative by beginning the epic with Columbo's dealings with Spanish royalty and ending with his "Regain[ing] the Spanish shores." ${ }^{51}$ Relatedly, the editors frame the entire sequence with Eliot's mock-Elizabethan stage directions from the Inventions appendix - the "Enter" and "Exeunt" of the king and queen.

All of these editorial choices bestow a spurious wholeness on fragments whose narrative, geographical, and characterological unity was never intended by their author. The world of Bolo was an imaginarium from which Eliot drew for ad hoc purposes of entertaining close friends. Although it had distinct, if shifting, logical markers and recurring themes and names, the Bolo sequence was never a narrative with beginning and end. It scarcely had distinguishable characters. Columbo and Bolo are so indistinct that even Bolo's queen is confused; accordingly, she names her unborn son "Boloumbo." 52 In their section of "Improper Rhymes" and their composite of the Bolo stanzas, Ricks and McCue have not made arbitrary or unwarranted decisions, but future commentators on the Bolo poems will need to distinguish what is editorially engineered from what is authorially intended. ${ }^{53}$

\section{Conclusion}

As with Eliot's serious literary ambitions in Inventions, the obscene verse is of a piece with the young artist's experimentation and increasing mastery. The Bolo poems, like his literary inventions, are rhetorical constructs whose voice is aimed at a specific audience and pitched for certain effects. In the literary verse of Inventions, such as "Portrait of 
a Lady" and "Prufrock," Eliot's critique of social convention and his exploration of poverty and alienation required him to cross mental borders that were strongly policed by his class and education. In the same way, the obscene poems enabled Eliot to cross heavily fortified borders. And perhaps the most difficult boundary to cross for someone of Eliot's class and temperament was the erotic boundary. Because the obscene verses adopt a tone of hysterical buffoonery rather than squalid fear, they do not breathe the same atmosphere of anguished sexuality found in the literary poems. Nevertheless, the scabrous verse still pushes against the same sexual and erotic boundaries as other poems in Inventions.

Even though the obscene poems can be seen as part of the same project as the notebook as a whole, they were detours from Eliot's project in a noteworthy sense: normally categorized as bawdy verse, they are also occasional poems. Though not written to commemorate a public event, they are still occasional in the sense that they were written for a specific communal setting: the social clubs of Harvard. We, their tardy and unwelcome readers, cannot recreate through the texts the living atmosphere of Eliot's exclusive, homosocial circle. That audience was wholly sympathetic because it would always be private and circumscribed. The poems speak to the already-known friends of the poet, and to those, like Lewis, who were introduced by known friends. The obscene verses do not seek to create a new readership, which is why they never seem to improve. The fumbling quality of the bawdy poems can be partly attributed to the audience for whom they were performed. The bawdy poems, to explain by analogy, might be compared to a composer's études. They were concoctions thrown off to entertain, experiments in rhythm and rudeness with no need to worry about an audience's potential rejection.

Once Eliot moved from America to England, the class and profession of men with whom he shared such lyrics changed, but key identity markers remained the same: the maleness of the club, their youth and sexual anxiety, a view of women's sexuality as passive, and an aggressive sense of themselves as shapers of their respective worlds. ${ }^{54}$ Compared 
to his new London coterie, Eliot was inexperienced, both sexually and literarily, and so he lead the charge with his Bolo poems. (None of his correspondents seemed to have written them, only received them.) Eagerly sharing via letters what had been sung at social clubs, he overcompensates with the bravado of the insecure, hoping to recreate in a new environment some of the atmosphere of Harvard.

We are now in a position to understand how the historical sketch that opened the essay is related to the rhetoric of the poems-how, in other words, these three aspects of audience are interdependent: (1) why Eliot never sought a public venue for these poems, (2) why the thrill of writing them waned early, and (3) why their rhetoric is essentially private. The obscene verses-especially the Bolo sequence as it expanded in the early teens-project a circumscribed audience whose expectations were mere titillation and friendly bonding. These expectations were bound to disappear as Eliot's relationships changed and as the cultural atmosphere in which he moved altered: Bloomsbury bohemians would not be so easily shocked as Boston Brahmins. With such a low bar of titillation, it is no surprise that the poems are dully repetitive and, for all their sexual and racial boundary crossing, artistically unadventurous. But perhaps this judgment is too severe. Even as a ten-year-old boy, in his Fireside compositions, Eliot clearly had a good ear for bad verse. That Eliot used such woeful doggerel as the vehicle for such ethically bad material is a way of satirizing the badness of both. Eliot might have been playing in ways that are too bad to be judged as merely bad. ${ }^{55}$

For the apprentice author of Inventions, the audience of the Bolo poems was private and real-the specific, nameable friends of the young Eliot-while the audience for the literary poems was imagined and aspirational. For a young artist who was struggling so mightily and alone to wrestle a new audience into shape, the freedom and ease of writing for a warmly accepting audience must have been a tremendous psychological relief. The audience for the bawdy verse kept him moving in the artistic direction toward which he was already oriented. 
The literary poems in the notebook, both the successes and the failures, were what made Eliot famous, because they called into being a peculiarly modern audience that had never existed before. By contrast, the obscene poems, because they were written for several dozen people, might seem to be interesting only because they were composed by a poet who became famous. This seems to be the conclusion reached by many reviewers and scholars. But once placed back into the chronology of their making, the obscene poems reveal not a step-wise progression in rhetorical mastery, but a liberated sense of audience.

Eliot would probably be exasperated to know that scholars were writing somber analyses of his bawdy poetry. One of his recurring jokes is that a pedant by the name of Prof. Dr. Krapp will take up the task of writing commentary on his Bolo poems. ${ }^{56}$ Exasperated Eliot might be, but he could not be surprised at this state of affairs, since he deliberately chose not to destroy the obscene verse. The influence of the obscene poems on his artistic project is perhaps the reason Eliot could never bring himself to destroy them, since they offered strangely occluded evidence of his expanding vision and his engagements with various audiences. As a young man tossing off such bawdy poems, he probably had little thought of what might become of them after they had been shared with their intended correspondents. Even so, once Eliot's fame escalated, he could easily have gotten rid of the obscene poems still in his possession. Eliot was not averse to burning sensitive material. Instead, he cut them out of the notebook and sent them to Ezra Pound, who valued the poems and who Eliot knew would preserve them. And, sometime in the future, Prof. Dr. Krapp and his colleagues would set to work on them.

\section{Notes}

1 IMH, 311 and 314-15.

2 Some of the important reviews of Inventions of the March Hare that address the ethical problems of the bawdy verse include Helen Vendler, "Writhing and Crawling and Leaping and Darting and Flattening and Stretching," London Review of Books, (October 31, 1996), 8-9; Louis Menand, "How Eliot Became Eliot" New York Review of Books 44, no. 8 
(1997), 26-29; Anthony Lane, New Yorker 73 (March 10, 1997), 86-92 (reprinted as "T. S. Eliot" in Nobody's Perfect, 438-48); Nicholas Jenkins "More American than We Knew," New York Times Book Review (April 1997), 14-15; Richard Poirier, "The Waste Sad Time," New Republic (April 28, 1997), 36-45; Stephen Romer, "The Hand of Laforgue's Shadow," TLS (April 3, 1998), 20; and Robert B. Shaw, "Prufrock redivivus," Poetry 171, no. 2 (1997), 162-68.

Pace Loretta Johnson's claim (“T. S. Eliot's Bawdy Verse," Journal of Modern Literature 27, no. 1-2 [2003], 14-25) that such material has not raised hackles is contested by some of the more lurid headlines including J. Bottum, "Pre-Prufrock: The Embarrassing T. S. Eliot," Weekly Standard 2, no. 31 (1997), 35; Michele Field's "Desanctification of Tomcat Eliot," Sydney Morning Herald (September 1996); Giles Foden, "Lost' Poems Explode Eliot Myth," The Guardian (August 23, 1996); and Bob Hoover, "Eliot's Poems Still Stirring Controversy" Pittsburgh Post-Gazette (April $27,1997)$. Subsequent scholarship on the Bolo poems is cited in the course of the essay, where I engage various claims in detail.

3 Poems 1 and Poems 2.

4 David Chinitz was the first to raise my suspicions on these matters, and this discussion is indebted to several conversations with him. With his permission, I have reworked some of our correspondence. Anthony Cuda and Jim McCue have helped me think through issues of dating and have directed me to pertinent sources, though I take responsibility for the conclusions reached herein. I am also grateful to Chris Buttram and Ellen Kriz for their critical feedback on early drafts, and to Emma Cheshire and Clare Reihill for permission to quote unpublished material.

5 "Given Eliot's desire to publish these poems, the protracted period of their composition, and the range of issues they invoke, we cannot, though, dismiss them as 'mere' juvenilia." Gabrielle McIntire, Modernism, Memory and Desire (Cambridge: Cambridge UP, 2008), 13.

6 The theory that Eliot intended to publish these poems in Blast is common among Lewis scholars as well (see Jeffrey Meyers, The Enemy: A Biography of Wyndham Lewis (London: Routledge, Kegan, and Paul, 1982), 76; Paul O'Keeffe, Some Sort of Genius: A Life of Wyndham Lewis (Berkeley: Counterpoint, 2000), 168). For Eliot scholars who have repeated some form of this narrative, almost any critic writing on Inventions will serve, but see especially Robert Crawford, Young Eliot (New York: Farrar, Straus and Giroux, 2015); Loretta Johnson, "T. S. Eliot's Bawdy Verse," Journal of Modern Literature 27, no. 1-2 (2003), 14-25; and McIntire, Modernism, Memory and Desire. I know of no critic who has disputed this narrative, one that I have unfortunately repeated in my own earlier criticism.

$7 I M H, 305$. Eliot's letter to Pound was first published in 1988, and Lewis's letter to Pound was published in 1985. Both letters were available to 
scholars for a few years before Ricks's volume appeared. But as evidenced by how widely Inventions of the March Hare was reviewed in the popular press, that volume reached a much broader audience than just literary scholars. By excerpting the Pound-Eliot-Lewis correspondence without any other context, Ricks's volume made it easy for reviewers and critics to draw inaccurate conclusions about the newly published Bolo poems and what seemed to be biographical evidence that Eliot had wanted them published.

8 L1, 64.

9 Poems 2, 272.

10 Pound/Lewis: The Letters of Ezra Pound and Wyndham Lewis. Edited by Timothy Materer (New York: New Directions, 1985), 9.

11 For this 1922 exchange, see $L 1,768 \mathrm{n} 1$ and 735 . Years later, Pound seems entirely sincere in suggesting that Eliot place Bolo, perhaps anonymously, in a collection of "Bawdy Ballads" - a suggestion that Eliot would sensibly ignore. Pound could never quite let the idea go, suggesting in 1935 to Arnold Gingrich that he should publish some Bolos by "father Eliot" (Ezra Pound, Selected Letters: 1907-1941. Edited by D. D. Paige. (New York: New Directions, 1971), 266).

12 Ezra Pound, “T. S. Eliot," in We Moderns: Gotham Book Mart, 1920-1940 (New York: Gotham Book Mart, 1940), 24-25.

13 The exact chronology of these undated letters is unclear. I have relied on Materer's order in Pound/Lewis, where he organizes the letters, as best he can, in chronological order.

14 Pound/Lewis, ed. Materer, 13.

15 Celia Marshik, British Modernism and Censorship (Cambridge: Cambridge UP, 2006), 3.

16 O'Keeffe, Some Sort of Genius: A Life of Wyndham Lewis, 155.

17 It might be argued that Eliot's contributions to Noctes Binanianae (1939) vitiates my point that he never sought to publish his scabrous verse. But the circumstances of that multi-authored collection prove rather than refute Eliot's extreme caution in this regard. Another elaborate in-joke among literary friends (Eliot, Geoffrey Faber, F. V. Morley, John Hayward), this volume of occasional verse commemorated the nights spent at Hayward's flat at Bina Gardens. The poems that had been circulating entre eux-mêmes were privately printed in an extremely limited edition of twenty-five copies, not for sale, with coded, semi-anonymous attributions. The assemblage of such verses into a book format does not constitute publication in the normal sense of that word-a work prepared for public sale; rather, it constitutes a memorialization of their friendship, a private keepsake of their homosocial bonds.

Putting aside such secrecy and caution, with the poems of Noctes Binanianae finally on view (see Poems 2, 205-38), it turns out that yet 
another critical consensus about Eliot's bawdy poems can be exploded. The verses that Eliot contributed to Noctes-long suspected of transgressive content-are so inoffensive that they might have been proclaimed from the pulpit of St. Stephen's without raising an eyebrow. Only in "Vers pour la Foulque" does a single, non-sexual reference to "nos culs" (our asses) bring these poems to the brink of bawdy (Poems 2, 230). And, as the editors describe in their commentary, this very poem was so harmless that Eliot considered publishing it in Pierre Leyris's edition of French translations of Eliot's poems (Poems 2, 230).

18 Valerie Eliot, "Letter" Times Literary Supplement (February 17, 1984).

19 Bryan Cheyette, "Eliot and 'Race': Jews, Irish, and Blacks," in A Companion to T. S. Eliot. Edited by David E. Chinitz (Malden, MA: Wiley-Blackwell, 2009), 335-49.

20 Donald Hall, “T. S. Eliot: The Art of Poetry," The Paris Review Interviews, vol. 1 (New York: Picador, 2006), 62-85.

21 McIntire, Modernism, Memory and Desire, 11.

22 McIntire, Modernism, Memory and Desire, 15.

23 Eliot to Clive Bell, January 3, 1941. Though the entirety of this letter is as yet unpublished, this sentence appears in a footnote in $L 3,509 \mathrm{n} 2$.

$24 \quad$ L3, 509.

25 I am indebted to Edward Mendelson for this nice phrase: "the moral urgency of scolding dead people." "A Different T. S. Eliot," New York Review of Books (February 22, 2016), 43-45.

26 See David Chinitz, “T. S. Eliot's Blue Verses and their Sources in the Folk Tradition." Journal of Modern Literature 23, no. 2 (1999-2000), 329-33. For an overview of the scholarship on the folk ballad "Christopher Columbo," see Ed Cray, The Erotic Muse: American Bawdy Songs, 2nd ed. (Urbana: U of Illinois P, 1999), 313-15.

27 Crawford, Young Eliot, 95-97 and 140-42.

28 Conrad Aiken, "King Bolo and Others," in T. S. Eliot: A Symposium. Edited by Richard March and Tambimuttu. (Chicago: Henry Regnery, 1949), 20-23.

29 Ricks and McCue seem to imply that the pocketbook is from 1915 (Poems 2 , 269), but in my examination of these manuscripts and the related circumstantial evidence (especially the appearance of British spellings), I am led to conclude that the pocketbook dates to the late teens.

30 L1, 94. The two new stanzas from 1923 explore, with mock-prudishness, the queen's pregnancy and the possible paternity of the "embryonic prince" (L2, 209 and Poems 2, 255). The mock-intellectual aspect that I identify can be traced as early as 1914, when Eliot imagines various scholars disputing philological niceties within the Bolo poems (L1, 46-47). Thus, the mock-intellectual and the shockingly ribald elements of the Bolo poems are not mutually exclusive. The point of the chronology 
offered here is to show how one clearly predominates over the other in different periods.

31 L3, 509.

$32 \quad L 4,109$.

33 The two Bolos addressed to Spencer have been published as stanzas 40 and 41 within The Columbiad (see headnote Poems 2, 270; for the poems, see Poems 2, 282 or L6, 514).

34 Eliot to Ezra Pound, December 28, 1934.

35 IMH, 318 and Poems 2, 274.

36 Eliot to Dobrée, August 10, 1930, in L5, 294. The similar quotation appears in the letter to Hayward, December 6, 1940.

37 Eliot to Hayward, November 25, 1940.

38 Eliot to Dobrée, August 6, 1941, in Poems 2, 249. Two seemingly related issues are ultimately red herrings: (1) By 1945 Eliot seems to have acquired a friend, whose last name is Coker and whose nickname was Bolo. It is unclear if Eliot is the one who has bestowed this nickname, but the conjunction of Bolo and Coker in the same personage is truly odd. (2) One word that had originated in Bolovian mythology but that later floated free of Bolovian contexts was the malleable term "Wux" (mainly in "Wux-Ho" and "wuxo"). Used as a farewell, it underwent a resurrection in the early 1940s.

$39 L 3,509$ n.

40 Eliot to Winthrop Sprague (“Nick”) Brooks, July 18, 1956.

41 See Crawford, Young Eliot, 95.

42 Huntington Library, Aiken Collection. On November 21, 1963, Eliot wrote to Aiken in a postscript: "Do you remember what happened when the Columbian crew were feasting at the Passover? If not, I will rehearse it to you." (Poems 2, 283n). This stanza, sent in late 1963 or 1964, is the promised rehearsal. These lines had appeared, in a different arrangement, in a letter (September 29, 1927) to Dobrée (see L3, 718-19), and the 1964 version as reproduced here appears in a slightly different arrangement in Poems 2, 283.

$43 \quad L 3,719$.

44 "Jewboys," L3, 718; "bastard jew," IMH, 315 and Poems 2, 271; "feasting at the Passover," L3, 719 and in Eliot to Aiken, 1964, Poems 2, 283.

45 IMH, 315 and Poems 2, 271.

46 Chinitz, “T. S. Eliot's Blue Verses," Journal of Modern Literature 23, no. 2 (Winter 1999-2000), 333.

47 Among Eliot's later correspondents, with the exception of Dobrée and Valerie Eliot, the recipients of recycled Bolo stanzas are his Harvard comrades and the friends he made in London circa 1914-15: Morris, Nick Brooks, Aiken, Pound, Lewis, and Spencer. (Although they did not matriculate at the same time, Eliot related to Spencer as a Harvard man.) 
48 The mildness of Eliot's verse in Noctes Binanianae confirms this pattern as well. Though one sonnet in that volume speaks of "crooning like a Harlem coon," the editors are correct in identifying the reference to what were widely described as "coon songs" (Poems 2, 225-26). The affectionate evocation of jazz culture in the Noctes sonnets contrasts with the racial ugliness of "Ballade pour la grosse Lulu." There are two descriptions of rape-in the Bolos sent to Spencer in 1932 (Poems 2, 282, stanza 41) and in an obscene poem sent to Pound on January 3, 1934-but I am arguing for a shift in emphasis, not a complete change.

49 The Bolo poems that I discuss herein are found in the published poetry, the published letters, and the unpublished letters. I have also relied on Ricks and McCue for their study of Valerie's Own Book, where several Bolo stanzas were copied by Eliot.

50 See Poems 2, 249 and 271, headnote.

51 Poems 2, 271 and 284.

52 Poems 2, 255.

53 A few decisions do seem inexplicable. Why is the sexually violent "Fragments" shamed as an "Improper Rhyme" (Poems 2, 285), while the offensively racist "Ballade pour la grosse Lulu" and obscene "Triumph of Bullshit" are classified neutrally as "Uncollected Poems" (Poems 1, 260 and 252), even though all three had been excised from the notebook by Eliot?

54 For more on the sociology of the bawdy tradition, see Ed Cray, The Erotic Muse: American Bawdy Songs, 2nd ed. (Urbana: U of Illinois P, 1999).

55 On the topic of form and doggerel, the reader may wish to compare the three bawdy limericks that Eliot wrote out for others: "There was a young lady named Ransome," "There was a young girl of Siberia," and "The Blameless Sister of Publicola" (Poems 2, 286, 287, and 290). As would be expected of the oral tradition from which they come, these limericks involve some elements of repetition and variation. What matters, then, is not whether they are wholly original to Eliot, but to what extent the tight rhythmic and formal constraints of the limerick contrast with the looser, open-ended ballad form in which the Bolo poems were written. The last limerick plays on lines from Coriolanus and Valerie's name, and is more likely original than the first. All three limericks are free of racist or misogynist content and are, in my estimation, more witty and delightfully obscene than all of the Bolo poems and Bolo prose combined.

56 He first appears as "Prof. Dr Krapp (Jena)" in a 1914 letter to Aiken (L1, 47 and subsequently in $L 3,820$ and $L 5,45)$. He is styled "Herr Dr Krapp of Wien" by Aiken (“King Bolo," 22). 